\title{
Modernising Various Crimes against the State
}

\author{
Graham McBain ${ }^{1,2}$ \\ ${ }^{1}$ Peterhouse, Cambridge, UK \\ ${ }^{2}$ Harvard Law School, USA \\ Correspondence: Graham McBain, 21 Millmead Terrace, Guildford, Surrey GU2 4AT, UK. E-mail: \\ gsmcbain@aol.com
}

Received: January 15, 2014 Accepted: February 10, $2014 \quad$ Online Published: May 28, 2014

doi:10.5539/jpl.v7n2p1 URL: http://dx.doi.org/10.5539/jpl.v7n2p1

\section{INTRODUCTION}

Today, most reasonable people - including lawyers and judges - would accept that English law should be intelligible, accessible and relevant to the society in which we presently live and not that of ages past. Further, most reasonable people would (probably) also accept that the power of the State in modern times is great. Among other things, it controls the armed forces, the police, the secret services and methods of surveillance. Thus, the State is perfectly capable of protecting itself in most instances, itself being the bureaucratic apparatus of government, the Crown, Parliament, the Cabinet etc. All the more reason then, that any criminal legislation whose purpose is to protect the State should be up-to date and intelligible. Also, limited in scope. That is, no more than is necessary in order not to infringe on individual freedoms and liberties.

Unfortunately, English criminal law in general contains much antiquated and obsolete legislation. ${ }^{1}$ This is particularly so in the field of 'State' crimes which (one would assert) cover crimes such as high treason, treason felony, terrorism, ${ }^{2}$ breach of official secrets, ${ }^{3}$ public order offences ${ }^{4}$ as well as one or two other pieces of isolated legislation.

The purpose of this article is not to consider high treason and treason felony since their abolition - or modernisation - has been considered in other articles. ${ }^{5}$ Further, legislation on terrorism and official secrets is relatively up-to-date and it has been considered in detail by many other legal commentators over the years. So too, legislation on public order offences, for the most part. Instead, this article intends to look at some isolated pieces of criminal legislation whose purpose is to protect the State in some form and which still exist - albeit they have arisen in historical circumstances very different to those prevailing in modern times. Thus, this article seeks to analyse the following with regard to their appropriateness today:

- $\quad$ Foreign Enlistment Act 1870. This makes it a crime for a British subject - without Crown licence - to enlist in the military or navy of a foreign State at war with a State with which the UK is at peace (a friendly State). It also makes it a crime for a person - without Crown licence - to build, issue any commission for, equip or despatch any ship with the intent or knowledge (or having reasonable cause to believe) that it will be employed in the military or navy of a foreign State at war with a friendly state;

\footnotetext{
${ }^{1}$ I have analysed this in a number of articles, including: (a) Abolishing High Crimes and Misdemeanours etc (2011) 85 Australian Law Journal 810-79; (b) Abolishing some Obsolete Common Law Crimes (2009) 20 King's Law Journal 89-114; (c) Abolishing Obsolete Legislation on Crimes \& Criminal Procedure (2010) Legal Studies, vol 30, no 3. See also n 5.

2 eg.Terrorism Acts 2000 \& 2006, Prevention of Terrorism Act 2005, the Anti-Terrorism, Crime and Security Act 2001.

${ }^{3}$ eg. Official Secrets Acts 1911, $1920 \& 1989$.

4 e.g. Public Meeting Act 1908, Public Order Acts 1936 and 1986, Vagrancy Act 1824, Town Police Clauses Act 1847 and Metropolitan Police Act 1839 (the latter three deal with street offences).

${ }^{5}$ (a) Abolishing the Crime of Treason (2007) 81 Australian Law Journal 94-134; (b) High Treason: Killing the Sovereign or Her Judges (2009) 20 King's Law Journal 457-88; (c) High Treason: Violating the Sovereign's Wife (2009) Legal Studies, vol 29(2) 264-80; (d) Abolishing the Crime of Treason Felony (2007) 81 Australian Law Journal 812-38.
} 
- Incitement to Disaffection Act 1934. This makes it a crime if any person maliciously and advisedly endeavours to seduce any member of Her Majesty's [HM's] forces from their duty or allegiance to HM; ${ }^{6}$

- Aliens Restriction (Amendment) Act 1919. This makes it a crime if any alien attempts (or does any act calculated or likely to) cause sedition or disaffection among any of HM's forces or the forces of her allies or among the civil population. It is also a crime if any alien promotes (or attempts to promote) industrial unrest in any industry in which he has not been bona fide engaged for, at least, two years immediately preceding in the UK.

The conclusion to this article may be stated at the onset. The Foreign Enlistment Act 1870 and the Aliens Restriction (Amendment) Act 1919 should be abolished and that the Incitement to Disaffection Act 1934 should be modernised.

\section{FOREIGN ENLISTMENT ACT 1870 - ENLISTMENT}

\section{(a) Early Background to the Act}

Pursuant to the Foreign Enlistment Act 1870 it is a crime for a British subject - without Crown licence - to enlist in the military (or navy) of a foreign State at war with a State with which the UK is at peace (a so-called 'friendly state'). Why this was made a crime has an early ancestry. It is grounded on the legal concept of British subjects swearing allegiance to the sovereign in return for protection. ${ }^{7}$ This relationship is a personal one; the sovereign is 'liege lord', the subjects 'liege subjects'. ${ }^{8}$ Halsbury notes:

English law is still informed by the ancient conception of the relationship between the individual and the state as being one between the subject and the monarch. The relationship of subject and monarch was conceived of as a personal one, involving a bargain under which the monarch gave the subject protection and undertook to govern according to the laws of the land, and the subject owed the monarch legally enforceable allegiance. It did not involve the subject having any legally enforceable rights against the Crown, and the duties of protection owed by the Crown were not justiciable. ${ }^{9}$

This allegiance was, essentially, a military one: ${ }^{10}$

- With the Norman Conquest in 1066, William I (1066-87) instigated a system of land tenure in which individuals were granted (or retained) land in England, in return for providing military service to the sovereign, when required. ${ }^{11}$ This grant (or retention) of land was evidenced by the swearing of allegiance to the sovereign by major landholders with their tenants then swearing allegiance to them. The effect was to create a hierarchical system of obligation in which land, allegiance and military service were the essential components; ${ }^{12}$

\footnotetext{
${ }^{6}$ The Act also makes it a crime if any person, with intent to commit (or to aid, abet, counsel, or procure the commission of) the crime referred to in the above text, has in his possession (or under his control) any document of such a nature the dissemination of copies thereof among members of HM's forces would constitute such a crime.

${ }^{7}$ The Crown's duty towards the subject originally rested upon a semi-feudal bond, whereby the king, as liege lord, was bound to maintain and defend his people in return for service and obedience. Calvin's Case (1608) 7 Co Rep 1 a at 4b (77 ER 377) 'as the subject oweth to the king his true and faithful legeance and obedience, so the sovereign is to govern and protect his subjects.' Also, 'it is truly said that protectio trahit subjectionem, et subjectio protectionem.'

${ }^{8}$ Halsbury, Laws of England (4 $4^{\text {th }}$ ed), para 29 'As, in feudal phraseology, the king was styled 'liege lord', so his subjects were termed 'liege subjects', and were bound as such to serve and obey him. Hence the duty of the subject towards the monarch is known legally as allegiance.' Allegiance may be natural, local or acquired. Local allegiance is due from all persons resident within the realm, and so long as they or their families or effects remain within the monarch's protection, they are punishable as traitors for acts of treason, whether their country is at amity with this country or not; but allegiance is not due from an alien enemy coming to invade the realm.'

${ }^{9}$ Ibid, n 8, para 26.

${ }^{10}$ This is no longer the case. Knight's service was abolished by the Tenures Abolition Act 1660. See GS McBain, Modernising the Monarchy - in Legal Terms (2010) King's Law Journal, vol 21(3), p 541.

${ }^{11}$ See GS McBain, Abolishing Obsolete Crown Prerogatives relating to Martial Law, Conscription \& Billeting. International Law Research (2012) vol 1, no 1, p 16.

12 Thus, in 1086, all the landholders in England were summoned to meet William I at Sarum (Salisbury) and to submit their lands to military tenure and take an oath of fealty. McBain, n 11, fn 29.
} 
- In early times - when the sovereign held land both in England and in France - to whom allegiance was owed was of great importance since a breach of it terminated the duty of the sovereign to provide military protection. Thus, in the reign of king John (1199-1216), to which sovereign (French or English) one swore allegiance to was especially acute when John lost Normandy and Anjou in $1204 .{ }^{13}$ As a result, he forced nobles with land and possessions both in France and in England to decide to whom they owed allegiance; ${ }^{14}$

- $\quad$ To formally renounce allegiance - called diffidatio (formal defiance) - often resulted in the crime of treason. ${ }^{15}$ At least from 1305 until the last civil war in England and Scotland - being the Jacobite rebellion of 1745 - the modus operandi of declaring civil war was the issue by the sovereign of a writ convoking his army (summonitio exercitus) and the raising of his standard (explicatio vexilli regis). ${ }^{16} \mathrm{~A}$ person owing allegiance to the sovereign who then opposed the standard was guilty of treason pursuant to the Treason Act 1351 (still extant) - the treason being that of levying war against the king in his realm (si home leve de guerre contre nre seignr le roi en son roialme). ${ }^{17}$ However, levying war against the sovereign was likely treated as treason even before this Act of $1351 .{ }^{18}$

Early sovereigns were also concerned about British subjects changing their allegiance since they might then assist a foreign State to attack the realm. ${ }^{19}$ This - and the fact that allegiance was so central to the ownership of land in England, military tenure and protection by the sovereign - meant that swearing allegiance to a foreign sovereign without the consent (licence) of the English sovereign - was likely a common law crime early on. Such a crime later became subsumed into the composite common law crime of 'contempt of the sovereign. ${ }^{20}$

- In respect of this common law crime, Hawkins - in his Treatise of the Pleas of the Crown written in 1716 - stated that it was a 'high...offence' to prefer the interests of a foreign prince to that of one's own and that it was criminal 'to do any thing which may but incline a man so to do', such as to receive a pension from a foreign prince without leave of one's sovereign;

- However, as Stephen points out - besides a breach of allegiance - it was not criminal to act as a foreign mercenary. ${ }^{21}$ Indeed, in medieval times it was common for British subjects to do so. ${ }^{22}$

\footnotetext{
${ }_{13}$ Acquitaine was confiscated in 1337 (precipitating the 100 Years War, 1337-1453). Calais (the final possession in France) was lost in 1558 .

${ }^{14}$ See also Roger of Wendover, Flowers of History (trans JA Giles, London, Henry G Bohn, 1849), vol 1, pp 213-4. For John's insistence on English nobles confirming their allegiance to him, see Ibid, pp 247-8.

${ }^{15}$ McBain, n 5, article (a), p 6.

${ }^{16}$ Sir Matthew Hale's Prerogatives of the King, DEC Yale (ed) Selden Society, vol 92 (London, 1976), p 127 'Regularly the time of war then begins when the King by his writ styled summonitio exercitus hath prefixed the convening of his army, the usual badge whereof is explicatio vexilli [regis] or the setting up of his standard.' In making this statement Hale referred to the time of Henry III (1216-72).

${ }^{17}$ McBain, n 5, article (a).

${ }^{18}$ Thus, some examples may be given of treason in the time of king John (1199-1216): (a) his nephew Arthur I (1187-1203), Duke of Brittany (1194-1202), disappeared in April 1203 after being imprisoned in France (in Falaise castle). It seems likely Arthur was put to death by John for treason, for being a traitor in breaking his allegiance to the same. See Roger of Wendover, n 14, pp $205 \& 369$. Also, the Treaty of Le Goulet signed by John and Phillip II of France on 22 nd May 1200; (b) Hugh de Gournaye (Hughes de Gournay (c 1148-1215), who held the castle of Montfort in France for John, renounced his allegiance to him. Ibid, p 207; (c) In 1213, John accused an English baron Robert Fitzwalter of treachery and rebellion, subsequently razing Baynard's castle held by him in London. Ibid, p 268. It may be noted that Fitzwalter often changed his allegiance. He was one of the barons who formally renounced his allegiance to John on 5 May 1215. He later paid homage to Louis (son of Philip Augustus of France) on 3 June 2016. Yet later, he paid homage to Henry III (1216-72) in October/November 2017. For the biographies of Arthur I and Robert Fitzwalter, see Oxford Dictionary of National Biography (ODNB).

${ }^{19}$ It is still treason under the Treason Act 1351 for a British subject to 'be adherent to the king's enemies in his realm, giving to them aid and comfort in the realm, or elsewhere.' See McBain, n 5, article (a), p 26.

${ }^{20}$ I say 'composite' since this category seems to have been effectively invented by William Hawkins, in his Treatise of the Pleas of the Crown ( $1^{\text {st }}$ ed, 1716-21, last ed 1824). See GS McBain, Abolishing some Obsolete Common Law Crimes (2009) 20 KLJ 89-114 in which it is argued that the crime of contempt of the sovereign is obsolete. See also E Coke, Institutes of the Laws of England (W Clarke \& Sons, London, last ed, 1824), vol 3, pp 139-42 (misprision).

${ }^{21}$ JF Stephen, A History of the Criminal Law of England (Macmillan \& Co, 1883), vol 3, p 257 'I am not aware of any evidence to show that till modern times the act of taking part in foreign hostilities was regarded as criminal unless the act involved some breach of duty towards the king. Indeed, the whole spirit of the feudal system was favourable to the notion that it was right and natural for soldiers to seek service wherever they could find it.' Stephen thought that the first occasion when this practice was interfered with was in 1605 (see legislation cited in the text).

${ }^{22}$ Russell, On Crime (12th ed, 1964), vol 2, p 1544 states that 'Entering into the service of a foreign sovereign without the consent of the king, or contracting with a foreign State any engagement which subjects the party to an influence or control inconsistent with the allegiance to our own sovereign, is said to be a misdemeanour.' Russell cites EH East, A Treatise of Pleas of the Crown (London, A Strahan, 1803), vol 1, p 81 and W Blackstone, Commentaries on the Laws of England (Oxford, Clarendon Press, $1^{\text {st }}$ ed, 1765-9, University of Chicago Press rep
} 
Hawkins, re the common law crime of contempt of the sovereign, cited various pieces of legislation preventing British subjects from undertaking foreign enlistment, all of which Acts have now been repealed. ${ }^{23}$ The legislation (it may be noted that there were also some early proclamations which sought to prevent the foreign enlistment of British subjects) ${ }^{24}$ which Hawkins cited comprised, in part, the following:

- $\quad$ Desertion. Acts of $1439,1491,1511,1548$ and 1713. These made it a felony for a soldier to quit his service without licence (i.e. to desert). ${ }^{25}$ An Act of 1715 made it a crime to seduce soldiers to desert; ${ }^{26}$

- $\quad$ Serving Foreign Princes. An Act of 1605 for discovering and repressing Popish recusants made it a felony for a subject to go abroad to serve any 'foreign prince state or potentate' if he had not previously taken an oath of allegiance to James I (1603-25). ${ }^{27}$ The Act also made it treason to attempt to absolve (or withdraw) any from their allegiance or to reconcile them to the Pope. ${ }^{28}$ An Act of 1735 made it a felony for a soldier to enlist in the service of any foreign prince, state or potentate. ${ }^{29}$ This Act was enlarged by one of 1756 which also made it a felony to enter into the military service of the French king; ${ }^{30}$ Both the legal text writers Kenny and Sir James Fitzjames Stephen, however, in his History of the Criminal Law of England, noted that this Act of 1736 'seemed to have remained a dead letter. 31

As Holdsworth notes, all these Acts were passed in the interests of the security of the English State and had no reference to the duties of a neutral State. ${ }^{32}$ In practice, therefore, until the Foreign Enlistment Act 1819, British subjects could enlist as mercenaries in foreign armies save where treaties provided otherwise ${ }^{33}$ and, although the

1979), vol 4, p122 (although Blackstone does not specifically deal with British subjects enlisting abroad in this citation). However, in the military area, this statement must be treated with caution not least since East was writing in 1803 and Blackstone in 1769 . Prior to the $19^{\text {th }}$ century one suspects that sovereigns generally were not too concerned about British subjects being foreign mercenaries. See also Halsbury, $\mathrm{n}$ 8 ( $\left.5^{\text {th }} \mathrm{ed}\right)$, vol 3, para 12, n 1 'Mercenary service abroad was very common before the passing of the Foreign Enlistment Act 1870 '.

23 See Hawkins, $n$ 20, (8 $8^{\text {th }}$ ed, 1824), vol 1, p 65.

${ }^{24}$ For example: (a) Proclamation of 26 October 1575 of Elizabeth I (1558-1603) which prohibited British mariners from serving foreign princes, see PL Hughes \& JF Larkin, Tudor Royal Proclamations (Yale UP, 1969), vol 2, p 395; (b) Proclamations of James I (1603-25) nos 1010 (1604-5) \& 1014 (1605) referred to in W Holdsworth, A History of English Law (Sweet and Maxwell, 2003 reprint), vol 4, p 298. Cf. vol 5, p 49 (in practice, service with foreign princes was permitted in these reigns save where specifically prohibited by the sovereign); (c) Proclamations of Charles II (1660-85), James II (1685-8) and William and Mary (1689-1702) cited in Holdsworth, vol 6, p 308, being those issued in 1674-6, 1687-8 \& 1697-8 which forbade English subjects enlisting in the service of a foreign prince or to assist the rebels of a foreign prince.

2518 Hen 6 c 19 (rep, the Statute Law Reform Act 1863). See also 7 Hen 7 c 1 (1491, rep. Ibid), 3 Hen 8 c 5 (1511 rep. Ibid), 2 Edw 6 c 2 (1548, rep Ibid) and 13 Anne c 10 (1713, rep Statute Law Reform Act 1867). See also Hawkins, n 20 ( ${ }^{\text {th }}$ ed, 1824$)$, vol 1, p 46 and Coke, n 20, vol 3, pp 80-1, 86-7.

261 Geo 1 st 2 c 47 (rep, Statute Law Reform Act 1867). See also the Opinion of judges in 1713 and 1721 that the Crown had no power to prohibit the building of ships of war or of great force for foreigners in any part of HM's dominions. Also, A-G v Sillem (1864) 2 H \& C 431 (159 ER 178) at p 453 .

27 The basis was, s 18, that 'It is found by late experience, that such as go voluntarily out of this realm of England to serve foreign princes, states, or potentates, are for the most part perverted in their religion and loyalty by Jesuits and fugitives, with whom they do there converse.' See also Holdsworth, n 24, vol 4, p 507 \& vol 14, p 75.

283 Jac 1 c 4 ss 18 \& 22 (rep, Religious Disabilities Act 1846, s 51). See also Hawkins, n 20, vol 1, p 46. CS Kenny, Outlines of Criminal Law (Cambridge UP, 1929), p 321 '[This] Act was passed with the object of preventing subjects of the Crown from being contaminated in religion or loyalty by the Jesuits whom they might meet in Continental armies.' Stephen, $\mathrm{n} 21$, p 258 'This was one of the most severe acts ever passed against Roman Catholics, and was one of several statutes produced by the excitement caused by the gunpowder treason...This statute assumes that to take foreign service is in itself lawful, though it attaches conditions to it which were at that time considered necessary.' See also East, n 22, vol 1, p 81

299 Geo II c 30 s 1 v(rep 1819). See also East, n 22, vol 1, p 81.

${ }^{30}$ Stephen, n 21, vol 3, p 258. See also 29 Geo II c 17 (rep 1819). See also Blackstone, n 22, vol 4, p 101 and Holdsworth, n 24 , vol 10, pp $376,400 \&$ vol 14, p 75.

${ }^{31}$ Kenny, n 28, p 321 (1929 ed). Also, 1966 edition of the same (the $16^{\text {th }}$ ed), pp 445-6. Stephen, n 21, vol 3, p 259 'In the debate on the Foreign Enlistment Act of 1819, Sir James Mackintosh [leader of the Whig party, see n 39] said that 'these acts were merely intended to prevent the formation of Jacobite armies in France and Spain'. It was also asserted by Sir Robert Wilson that the acts 'remained during all times a dead letter on the statute book.' [Stephen refers to Hansard xl 869-870, June 3, 1819]. Stephen stated that prisoners taken from the Irish brigade at Fortenoy, Dettingen, Minden, and Culloden [these battles were in 1745, 1743, 1759 and 1746 respectively], were treated not as criminals, but as prisoners of war. He also said that 'at one period, out of 120 companies of Austrian grenadiers, seventy were commanded by Irish officers,' and that, when the officers of the Irish brigade refused to serve the republic after the revolution, they were received into the British service, and five or six regiments were embodied and put under their command. In short, down to the end of the eighteenth century it was not in practice considered improper for persons who were so disposed to seek military service where they pleased, and writers on international law maintained that neutral nations were under no obligation to belligerents to prevent neutral subjects from engaging in the service of either belligerent as they might feel disposed.'

${ }^{32}$ Holdsworth, n 24, vol 14, p 75.

33 Ibid, p 74 refers to WE Hall, International Law (Clarendon Press, 1909, $6^{\text {th }}$ ed), pp 580-3 who cites instances of troops being supplied to belligerents under neutral treaties as well as treaties which stipulated against this. Also, instances in which neutral states bound themselves 
Acts of 1605,1736 and 1756 were on the statute book (as well as various proclamations having been made), they were generally ignored. The reason for this lassitude is likely that British subjects acting as foreign mercenaries did not, in practice, cause serious political or diplomatic damage to the British government.

\section{(b) Foreign Enlistment Act 1819}

The first British Act on foreign enlistment which was effectively enforced was the Foreign Enlistment Act 1819. This was preceded by earlier US legislation of 1794. Holdsworth, citing Hall's text on International Law, states that:

It was not until the end of the eighteenth century that international lawyers began to be of opinion that a state which permitted a belligerent to levy troops in its territory, or to equip armed ships to be used in its service, infringed its obligations as a neutral. ${ }^{34}$

On the outbreak of Anglo-French war (1793-1802) the US Secretary of State, Thomas Jefferson, in his letter to M Genet (the French ambassador to the US in 1793-4) (35 $^{35}$ justified the refusal of the US to allow any of the warring States to equip, arm or man vessels of war, or to enlist troops in the neutral territory, on the ground that the US was at peace with all the warring states and that, therefore, US citizens were not at liberty to exercise acts of war against any of them:

For the citizens of the United States, then, to commit murders and depredations on the members of other nations, or to combine to do it, appeared to the American Government as much against the laws of the land as to murder or combine to murder or rob their own citizens. ${ }^{36}$

As a result, an Act of Congress was passed in 1794 to deal with foreign enlistment (it was re-enacted in 1818). This was not to be replicated in England until the Foreign Enlistment Act 1819. As to the latter, Sir James Fitzjames Stephen notes that:

a bill was introduced into Parliament by Lord Liverpool's government ${ }^{37}$ closely resembling the one passed in America in 1818. It was to some extent defended, especially by Mr Canning, ${ }^{38}$ on grounds somewhat similar to those just stated, but its immediate practical object was to prevent the enlistment of men, and the equipment of ships in England, in aid of the South American Spanish colonies, then in revolt against old Spain, and on this ground it was strenuously opposed by Sir James Mackintosh, ${ }^{39}$ Lord Brougham, and other liberal members of Parliament. ${ }^{40}$

The Foreign Enlistment Act $1819^{41}$ made it a misdemeanour (punishable by fine and imprisonment) for a British subject, without licence, to serve in the military or navy of a 'foreign prince, state, potentate, colony' etc. ${ }^{42}$

not to allow belligerents to levy troops within their territory. Cf. Holdsworth also cites G Chalmers, Opinions of Eminent Lawyers (Reed and Hunter, 1814), vol 2, pp 328-9 in which Doctors Exton and Lloyd (as legal advisers) opined, in 1677, that those who broke such treaties were guilty of a misdemeanour and that those who took commissions from a foreign power to cruise against the allies of the sovereign were also guilty of the same.

${ }^{34}$ Holdsworth, n 24, vol 14, p 76 quoting Hall, n 33, pp 578-85 who also notes that some of the Italian states and the United Provinces were the first to prohibit their subjects from fitting out armed ships for belligerents.

${ }^{35}$ This is Edmond Charles Genet (1763-1834). On the Act of 1819, and the prior US position, see generally FW Gibbs, The Foreign Enlistment Act (William Ridgway, 1863). For Mr Genet, see Ibid, p 10 et seq.

${ }^{36}$ Stephen, n 21, vol 3, p 259 referring to American State Papers, vol 1, p 155. See also Holdsworth, n 24, vol 14, p 76. Also, A-Gv Sillem (1864) $2 \mathrm{H} \& \mathrm{C} 431$ (159 ER 178) at p 444-53 (it contains a useful analysis of the US law and how the Foreign Enlistment Act 1819 came about).

${ }^{37}$ Lord Liverpool was Prime Minister from 1812-27, leading a Tory government.

${ }^{38}$ Stephen, n 21, vol 3, p 259, n 1 refers to George Canning's speech of 10 June 1819, see Hansard, vol xl, pp 1102-10. At the time Canning (who was later to become Prime Minister) was President of the Board of Control in the government of Lord Liverpool.

${ }^{39}$ Sir James Mackintosh was leader of the Whig party who sympathised with the claims of the Spanish colonies to seek their independence from Spain.

${ }^{40}$ See also Holdsworth, $\mathrm{n} 24$, vol 13, pp 216-7 'there is no doubt that the Act gave a much needed but, as events later in the century showed, an insufficient power to the State to compel its subjects to observe the obligations of neutrality.' See also Ibid, vol 14, p 32.

${ }^{41} 59$ Geo 3 c 69 (repealed by the Foreign Enlistment Act 1870). Stephen, n 21, vol 3, p 261'This act is extremely elaborate and verbose.' See also Holdsworth, $\mathrm{n} 24$, vol 14, $\mathrm{p} 77$ and $A-G$ v Sillem (1864) 2 H \& C 431 (159 ER 178) at p 453 et seq.

42 'If any natural-born subject of $[\mathrm{HM}]$...shall take or accept, or shall agree to take or accept any military commission, or shall otherwise enter into the military service as a commissioned or non-commissioned officer, or shall enlist or enter himself to enlist, or shall agree to enlist or enter himself to serve as a soldier, or to be employed or shall serve in any warlike or military operation in the service of or for or under or in aid of any foreign prince, state, potentate, colony, province or part... or in any other military capacity; or [agree to enlist or serve as a sailor or marine in respect of the same etc].' See also Hawkins, n 21, ( $8^{\text {th }}$ ed, 1824), vol 1, p 46. 
Kenny - in his text on Criminal Law- notes of this Act that it was passed 'to restrain outbursts of sympathy with the revolt of Spain's South American colonies against her. ${ }^{43}$ This Act is not considered further in this article since it was replaced by the Foreign Enlistment Act 1870 (see below). However, three cases under this Act of 1819 may be noted:

- $\quad R v$ Carlin $(1870)^{44}$ was an appeal to the Judicial Committee of the Privy Council (JCPC) from the decision of a deputy judge of the Vice-Admiralty court of Bahamas. The appeal turned on the alternative wording of the Act; ${ }^{45}$

- In $A-G v$ Sillem (1864) $)^{46}$ a ship (called the Alexandra) was seized by British Customs. It was built for the Confederate States in the US to be used as a ship of war. However, she was not fully equipped as such. Nor, in the jury's opinion, was the ship intended to be so equipped in any English port. The English court held, in substance, that an incomplete equipment was not a crime within the Foreign Enlistment Act 1819. ${ }^{47}$ This defect in the Act was repaired in the 1870 Act (see below); ${ }^{48}$

- Grazebrook, Re, ex p Chavasse (1865). ${ }^{49}$ If a British shipbuilder builds a vessel of war in an English port and arms and equips her for war bona fide on his own account as an article of merchandise - and not by virtue of any agreement, understanding or concert with a belligerent power - he may lawfully, if acting bona fide, send the ship so armed and equipped for sale as merchandise in a belligerent country, and in so doing will not violate the Act.

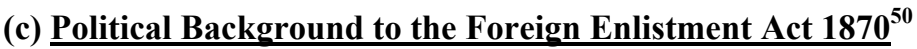

In 1868 a royal commission recommended material changes to the Foreign Enlistment Act 1819 in order to amend and expand it. ${ }^{51}$ The biographer John Morley, who wrote the standard biography of Gladstone, noted - in respect of this Act - in which Gladstone was involved, that a:

new law was passed, greatly strengthening the hands of the executive, and furnishing due means of self-protection against such nefarious manoeuvres as those of the Alabama. ${ }^{52}$

\footnotetext{
${ }^{43}$ Kenny, n 28, p 321. Also 'The ancient powers of the Crown in England being insufficient to enable it to prevent its subjects from committing acts which might be at variance with the modern conceptions of the obligations of neutrality, Parliament found it necessary to make participation in foreign hostilities a criminal offence.'

${ }^{44}$ (1870) 6 Moo NS 509 (16 ER 818). See also $R$ v Jones and Highat (1864) 4 F \& F 25 (176 ER 450) (guilty of engaging and procuring men to enlist as sailors in the service of a foreign belligerent State).

${ }^{45}$ An insurrection occurred in Cuba (then a dependency of Spain). The Governor of the Bahamas issued a proclamation indicating that Great Britain was at peace with Spain and that British subjects and others residing in the Bahamas should refrain from acts which would be construed as a violation of amicable relations between the same. Reference was also made to the Foreign Enlistment Act 1819, s 7 (this is now covered, albeit with different wording, by the Foreign Enlistment Act 1870, s 11 - fitting out naval, or military, expeditions without licence). Subsequent to the issue of the proclamation a ship (called the Salvador) bearing Cubans and with some arms which was making for Cuba was seized in Bahamian waters by the Receiver General and Treasurer of the Bahamas for a breach of s 7. The appeal to the JCPC was on a narrow point of law of whether it was necessary to prove for the purposes of $\mathrm{s} 7$ whether the vessel was engaged in aiding parties in insurrection against a foreign government since they did not assume to exercise the powers of government over any portion of the territory of such government. See also Holdsworth, n 24, vol 14, p 78. Also, Burton v Pinkerton (1867) LR 2 Ex 340 per Kelly CB (to serve on board a vessel used as a store ship of a belligerent, the fitting out of which is to be so used, is an offence under $\mathrm{s} 7$ of the Act).

${ }^{46} 2$ H \& C 431 (159 ER 178). See also Holdsworth, $\mathrm{n} 24$, vol 14, p 78. Also, R v Rumble (1864) 4 F \& F 175 (176 ER 519) (the case related to whether the defendant engaged men on board ship with intent to enlist them in Confederate service. Found not guilty.

${ }^{47}$ See also Stephen, n 21, vol 3, p 262.

${ }^{48}$ Stephen, n 21, vol 3, p 262 'The 'provisions [of the 1870 Act] as to providing ships of war for foreign belligerents are much more stringent than those of the act of 1819 .'

494 De GJ \& Sm 655 (46 ER 1072). See also $R v$ Granatelli (1849) 7 ST NS 979. This comprised a prosecution under 1819 Act, s 7 which was brought by the Sicilian Minister in London against prince Granatelli and others for fitting out, without licence, the SS Bombay to be used in hostilities against the King of Two Sicilies, with whom the UK was at peace. Found not guilty).

${ }^{50} 33$ \& 34 Vict c 90. See also Archbold, Criminal Pleading, Evidence and Practice (Thompson Reuters, 2013), para 25-297 'The Act was designed to regulate the conduct of British subjects during the existence of hostilities between foreign States with which the UK is at peace. It applies to all Her Majesty's dominions and their territorial waters.' For discussion of this Act see GJ Wheeler, Foreign Enlistment Act (Eyre \& Spottiswoode, 1896). For articles see P Morris, The Foreign Enlistment Act 1870: When Will It Be Abolished ? Solicitor's Journal 1986, vol 130(5), pp 271-2 and J Jaconelli, The Recruitment of Mercenaries and the Foreign Enlistment Act 1870. Public Law 1990, pp 337-41.

${ }^{51}$ Report of the Neutrality Laws Commissioners, Parliamentary Papers (1867-8). It recommended that the Foreign Enlistment Act 1819 should be amended, and extended, in such a way that the Crown was given sufficient power to fulfil the obligations of the UK as a neutral state. See also Holdsworth, n 24, vol 14, p 78 and Russell, n 22, pp 1545-8.
} 
The background to this reference to the Alabama is that:

- During the American Civil War (1861-5) various Confederate warships were built in the UK. These, which often had British subjects as crew members, later did considerable damage to the American (Union) merchant marine;

- The most famous of these was the CSS Alabama ${ }^{53}$ which the British Government failed to detain in the UK when it was being built there although it was aware of her construction. ${ }^{54}$ Compensation was later paid by the UK government to the US government, pursuant to an international arbitration. ${ }^{55}$

Thus, the Foreign Enlistment Act 1870 was enacted to seek to prevent the UK becoming embroiled in embarrassing diplomatic and political situations where British subjects enlisted to fight against friendly States or where ships were being built in the UK to be used against friendly States. ${ }^{56}$ Sir James Fitzjames Stephen (writing in 1881) did not think much of the rationale behind the repeal of the Foreign Enlistment Act 1819 and the enactment of the Foreign Enlistment Act 1870:

It was contended by the Americans, and denied by the English, that according to international law the English were bound to prevent what were described as breaches of neutrality, and it seems to me that the controversy supplied a good illustration of the worthless, inconclusive nature of such discussions. The real question was, whether the Americans thought the inconvenience of the English assistance to the Confederate States serious enough to go to war about; and whether the English thought the advantage of being able to build and sell such ships worth fighting for. To suppose that a great nation would submit to having its commerce ruined or would suppress an important branch of trade because Vattel had said something implying the one inference or the other appears to me to be absurd. The utmost that writers on international law can really do in such cases is to furnish decorous and plausible excuses for foregone conclusions. As for the Foreign Enlistment Act [1819], it was obvious enough that it had nothing to do with the question between the two nations. The American complaint was equally well or ill founded whether the Foreign Enlistment Act did or did not enable the government to prevent British harbours from being turned into naval stations for the Confederates. If it did, their complaint was that it was not used. If it did not, their complaint was that it was ineffectual. ${ }^{57}$

Other commentators on the Foreign Enlistment Act 1870 argued that it went beyond what international law required and made a new crime - that of building a ship which was not forbidden either by the law of nations or by other municipal laws. ${ }^{58}$

\section{(d) Provisions of the Foreign Enlistment Act 1870}

This Act, ${ }^{59} \mathrm{~s} 4$, makes it a crime (one of 'illegal enlistment') for a British subject to enlist in the military or navy of a foreign state at war with a state with which the UK is at peace, a so-called 'friendly State.' Also, if a person induces another to accept (or agree to accept) such enlistment. Thus, s 4 (penalty on enlistment in service of foreign state) provides that it is a crime:

\footnotetext{
${ }^{52} \mathrm{~J}$ Morley, The Life of William Ewart Gladstone (Macmillan \& Co, 1903), p 399. He also noted that Sir William Harcourt [appointed Whewell Professor of International Law at Cambridge in 1869] called the Act 'the best and most complete law for the enforcement of neutrality in any country.' See also Hansard, speeches of August 1, 3 and 4 of 1870.

${ }^{53}$ See Morley, n 52, vol 2, ch 9. See also Holdsworth, n 24, vol 14, p 78 and P Cobbett, Leading Cases on International Law (4 ${ }^{\text {th }}$ ed), vol 2 , pp 451 et seq.

${ }_{54}$ Ibid. The Alabama was built by Cammell Laird in Birkenhead in 1862. Morley, n 52, p 395 'After the Alabama, no vessel on which the American [Union] minister had made representation to the foreign office succeeded in quitting a British port.'

${ }_{55}$ Ibid. An international arbitration in Switzerland (Geneva) held the UK liable to pay US\$15.5m compensation for damages due to several warships built in Britain and sold to the Confederacy.

${ }^{56}$ Kenny, n 28, pp 321-2 'During the American civil war, [the Act of 1819] proved insufficient to prevent the traffic between English shipbuilders and the Confederate government; and was accordingly replaced in 1870 by a more stringent standard.'

${ }^{57}$ Stephen, n 21, vol 3, p 261. For the reference to Vattel, see $A-G v$ Sillem (1864) 2 H \& C 431 (159 ER 178) at p 442. See also E de Vattel, The Law of Nations (Liberty Fund, 2008), p 526 (Bk 3, ch 7, s 110).

${ }^{58}$ Morley, n 52, vol 2, p 405. See also H Wheaton, Elements of International Law (ed Boyd, Stevens, $2^{\text {nd }}$ ed, 1880), p 509-11 (on the 1819 Act) and pp 524-5 'no doubt that the Act of 1870 is in excess of what international law requires as the duty of a neutral'. See also TJ Lawrence, Principles of International Law (Macmillan, $1^{\text {st }}$ ed, 1895), pp 553-4.

${ }^{59}$ It is entitled 'An Act to regulate the conduct of Her Majesty's subjects during the existence of hostilities between foreign states with which Her Majesty is at peace.' For a brief summary of the Act, see SF Harris, Principles and Practice of the Criminal Law (Sweet \& Maxwell, 1950), pp 114-6. See also edition of 1881, pp 59-61.
} 
If any person, without the license of $[\mathrm{HM}],{ }^{60}$ being a British subject, within or without [HM's] dominions, ${ }^{61}$ accepts or agrees to accept any commission or engagement in the military ${ }^{62}$ or naval service $^{63}$ of any foreign state ${ }^{64}$ at war with any foreign state at peace with [HM], and in this Act referred to as a friendly state.

It is also a crime:

whether a British subject or not within [HM] dominions, induces any other person to accept or agree to accept any commission or engagement in the military or naval service of any such foreign state as aforesaid.

In either of these instances, the punishment is a fine and imprisonment or either of such punishments at the discretion of the court. However, imprisonment must not exceed 2 years. ${ }^{65}$ As well as these crimes, there are three other crimes in the Act relating to enlistment. These are of a supplementary nature since they seek to prevent the first two offences being committed by targeting the only means of transport for a British subject seeking to go abroad in 1870 - by ship. Thus, the Act makes it a crime:

- For a British subject to quit ${ }^{66}$ (or board) a ship intending to accept a military or naval commission with a State at war with a friendly state. Also, for a person to induce this; ${ }^{67}$

- For a person to induce another to embark on board a ship with the intent (or in order) to accept such a commission; ${ }^{68}$

- If a shipowner (or master) without licence takes on board a ship (or agrees to do so) illegally enlisted persons. $^{69}$

These crimes may be ignored for present purposes since - as well as no one ever having been prosecuted under them - they can be easily circumvented today by any person seeking to enlist with a foreign State taking an aircraft or a train in order to leave the UK, rather than boarding (or quitting) a ship. Therefore, the key section of the Foreign Enlistment Act 1870 re enlistment is s 4 previously mentioned, about which the following may be noted:

- It only applies to British subjects - whether in, or outside, HM's dominions;

- It applies only if, without HM's licence, they accept (or agree to accept) any commission or engagement in a foreign military or naval service;

${ }^{60} \mathrm{~S} 15$ ' ... a license by [HM] shall be under the sign manual of [HM], or be signified by Order in Council or by proclamation of [HM].'

${ }^{61}$ The Act, s 2, provides that it 'shall extend to all the dominions of [HM] including the adjacent territorial waters.' See also 81 Modern Law Review (1965) 533 (does not include foreign recruiting officer on foreign soil).

${ }^{62}$ S 30 (interpretation) "Military service" shall include [military telecommunications] and any other employment whatever, in or in connexion with any military operation.' The wording in brackets was added by the Telecommunications Act 1984.

${ }^{63}$ Ibid. "Naval service" shall, as respects a person, include service as a marine, employment as a pilot in piloting or directing the course of a ship of war or other ship when such ship of war or other ship is being used in any military or naval operation, and any employment whatever on board a ship of war, transport, store ship, privateer or ship under letters of marque; and as respects a ship, include any user of a ship as a transport, store ship, privateer or ship under letters of marque.' Letters of marque are obsolete and privateering was abolished in 1856. See GS McBain, Abolishing Obsolete Crown Prerogatives relating to the Military (2011) Nottingham LJ, vol 20, pp $20-3$.

${ }^{64}$ Ibid. "Foreign state" includes any foreign prince, colony, province, or part of any province or people, or any person or persons exercising or assuming to exercise the powers of government in or over any foreign country, colony, province, or part of any province or people.'

65 Ss $4 \& 13$.

${ }^{66}$ Vis-à-vis this section, in the Spanish Civil War (see (f) later in the text), R Baxell, Unlikely Warriors (Aurum Press, 2012), $\mathrm{p}$ 77, noted that a number of volunteers jumped ship (including deserting from British naval vessels) in order to join the Republicans. It also seems that a number of British volunteers in the British Battalion had deserted from the British army, Ibid, p 119. However, none of them were prosecuted under the Act.

${ }^{67}$ S 5 (penalty on leaving HM's dominions with intent to serve a foreign state) 'If any person, without the licence of [HM], being a British subject, quits or goes on board any ship with a view of quitting [HM's] dominions, with intent to accept any commission or engagement in the military or naval service of any foreign state at war with a friendly state, or, whether a British subject or not, within [HM's] dominions, induces any other person to quit or to go on board any ship with a view of quitting [HM's] dominions with the like intent...'

${ }^{68} \mathrm{~S} 6$ (penalty on embarking persons on board ship under false representations as to service) 'If any person induces any other person to quit [HM's] dominions or to embark on any ship within [HM's] dominions under a misrepresentation or false representation of the service in which such person is to be engaged, with the intent or in order that such person may accept or agree to accept any commission or engagement in the military or naval service of any foreign state at war with a friendly state...'.

${ }^{69} \mathrm{~S} 7$ (penalty on taking illegally enlisted persons on board ship) 'If the master or owner of any ship, without the license of [HM], knowingly either takes on board, or engages to take on board, or has on board such ship within [HM's] dominions, any [illegally enlisted persons] ... ' 
- $\quad$ This service must be with a State at war with a friendly State;

- The Act also applies to British subjects in the Channel Islands ${ }^{70}$ as well in the 'Dominions.' Today, the latter appears to cover British subjects (it can only apply to them) living in any of the British Overseas Territories (BOT). ${ }^{71}$ However, the number of British subjects in BOT is likely to be very small. ${ }^{72}$ Thus, the prospect - in modern times - of large numbers (or any) of them enlisting in the military or navy of States at war with a State friendly to the UK, may be dismissed as remote. As a result, the continued worth (or not) of this Act really applies to the UK - as opposed to the Channel Islands or BOT.

\section{(e) Problems with the Foreign Enlistment Act 1870 re-Enlistment}

Today, there are many problems with this crime of enlistment:

- $\quad$ British Subjects. This crime can only be committed by British subjects. Thus, it cannot be committed by foreigners living in the UK. Nor by any other category of persons who are not British subjects (such as British citizens etc). ${ }^{73}$ Determining who is a British subject today would involve the British authorities in checking a passport and probably other background details - something a potential mercenary would be unlikely to disclose; nor the fact that they have enlisted (or intend to) in a foreign army or navy. Thus, this crime only applies to a restricted category of persons and it cannot readily be policed (difficulties with policing would apply even more so in the case of BOT) ${ }^{74}$

- Military or Navy - not Air Force. Reference is made in the Act only to a foreign 'military or naval' service. Thus, since the Act is prior to the development of military aviation, it does not make it crime for a British subject to join any air force. ${ }^{75}$ Nor, indeed, any other service - bar a military or naval one. As a result, if a 'special' service was set up by the foreign State, it would seem that a British subject would not fall foul of this if he enlisted in the same. ${ }^{76}$ In short, it is very easy to circumvent the Act;

- $\quad$ Need for War. No crime is committed in any case unless the State, whose military or navy the British subject joins, is at 'war'. In 1870 (the time of the Act) the general convention was for States to declare war - and for 'war' to be such. Thus, it would not have included peace keeping missions, indeed, nothing less than a full scale war including invasion of territory such as the Franco-Prussian war of $1870-71 .^{77}$ Today, however, it is rare for foreign States to declare war or to engage in such. Engagements tend to be much more restricted. In short, 'war' in the sense envisaged in 1870 is declining;

- Civil War. It is dubious whether the Act is sufficiently well drafted to over civil war, in practice, since it refers to two separate States - one in which a British subject enlists and another with which that State is at

\footnotetext{
70 S 30 (interpretation) defines the UK to include them as well as Alderney and Sark (adjacent territories).

71 BOT comprise: Akrotiri \& Dhekelia, Anguilla, Bermuda, British Antarctic Territory, British Indian Ocean Territory, British Virgin Islands, Cayman Islands, Falkland Islands, Gibraltar, Monserrat, Pitcairn Islands, St Helena, Ascension and Tristan de Cunha. See also s 30 (interpretation) 'British possession" means any territory, colony, or place being part of [HM's] dominions, and not part of the United Kingdom as defined by this Act.'

72 The British Antarctic Territory, South Georgia and the South Sandwich Islands host only officials and research staff, the British Indian Ocean Territory and Base Areas of Cyprus only have military personnel.

73 See also Halsbury, $\mathrm{n} 8$ ( $\left.5^{\text {th }} \mathrm{ed}\right)$, vol 3, para 12 , fn 2 'this term is now used for a very limited class of persons.'

74 See $n 72$.

75 Cf. Halsbury, n 8 ( $5^{\text {th }}$ ed), vol 3, para 12, fn 4 referring to Dyke v Elliott (1872) 8 Moo NS 428 (17 ER 373 ) at p [192] (definitions in the Foreign Enlistment Act 1870 are not restrictive but inclusive). However, it is too great an extension (it is asserted) to argue that the Foreign Enlistment Act 1870 retrospectively applies to the air force of a belligerent State. See also Report of the Committee of Privy Counsellors appointed to inquire into the recruitment of Mercenaries (Cmnd, 6569, 1976), para 25 (it refers to the strict interpretation of penal statutes).

${ }^{76}$ To re-read into the Act of 1870 its application to aircraft (only first used in warfare in the $1^{\text {st }}$ World War (1914-18)) would be an unwarranted constructive extension of the Act. In the case of a 'special' service, the definition of 'military service' in the Act (see $\mathrm{n}$ 62) would have to be widely interpreted. For example, if a person works as a typist or cook or photographer or code-breaker in the foreign warring State does this comprise this 'military service'?

77 See also Halsbury, n 8 ( $5^{\text {th }}$ ed $)$, vol 3 para 12, n 7 'Since the Foreign Enlistment Act 1870 is a criminal statute it is uncertain whether 'war' for these purposes includes an international armed conflict which has not resulted from a declaration of war or a non-international armed conflict (given the definition of a 'foreign State' in s 30...).' For the definition of a 'foreign State' see n 64.
} 
war (a friendly State). ${ }^{78}$ As a result, HM government would have to recognise each side to the civil conflict as the de facto and the de jure government respectively - something most unlikely; ${ }^{79}$

- Friendly State - UK also at War. For the Act to apply, the State in question must also be at war with a friendly state. Thus, no crime is committed if the UK is also at war with that friendly state. Further, today, British foreign policy is not determined solely on the basis of the UK being at war - or at peace - with States. For many States (especially those at a geographical distance to the UK) there likely be no real pre-occupation or concern to the Government for British (subjects) mercenaries to be fighting against them. For example, if British subjects joined the South Korean army who were at war with North Korea, would they really be prosecuted under this Act, North Korea being held to be a friendly State? What interest would the British Government have in doing this? What public purpose would really be served by imprisoning British subjects in such circumstances?

- $\quad$ Commonwealth States. As a Report of a Committee of Privy Counsellors on Mercenaries of 1976 (hereafter the ' 1976 Report') points out, no Commonwealth country (of which there are now 53) nor the Republic of Ireland would comprise a 'foreign State' within the meaning of the Act; ${ }^{80}$

- $\quad$ Terrorism. This Act has no application whatsoever to modern day terrorists who join foreign political, or other, organisations engaged in armed struggle. Even if such persons comprise British subjects, they are not joining the military (or navy) of a State at war with another State;

- Omissions and Obscurities. The 1976 Report referred, in respect of the provisions on illegal enlistment, to the many omissions and obscurities in the Foreign Enlistment Act 1879. In particular, it stated that: 'The statutory language used in the Act to create offences [re illegal enlistment] is adapted to conditions as they existed in 1870 as respects relations between sovereign states, the kinds of armed conflict that had taken place in foreign territory during the previous decades and the means of transport and of waging war that were then available. The immense changes in those conditions which have taken place in the last hundred years and particularly since World War II have resulted in there being important omissions from the Act and a number of obscurities in the statutory language affecting most of the ingredients of the offences'; 81

- Evidential Difficulties. The Act - being a penal statute - would require proof of what the accused had actually done in the foreign country with sufficient particularity to justify a conviction for having enlisted in the forces of a belligerent State ${ }^{82}$ (it is important to note that the crime is enlistment - not service with the belligerent State). It is most unlikely that persons best able to give evidence - fellow enlistees - would provide evidence.

In conclusion, a coach and horses can be driven through the Foreign Enlistment Act 1870.

\footnotetext{
${ }^{78}$ This was one of the problems in relation to British subjects enlisting to fight in the Spanish civil war, see (f). See also Report, $\mathrm{n} 75$, paras $26 \& 34$.

${ }^{79}$ Report, n 76, para 35 'In a prosecution for illegal enlistment or recruitment under the Act it would thus be necessary to prove that [HM's] government had recognised the persons on whose behalf the armed force was raised and the opponents against whom they were fighting as being de facto and de jure governments at the time that the accused enlisted.' Also, para 36 'It is accordingly doubtful whether the Act could ever apply to enlistment in guerrilla forces or in security forces engaged in their suppression if the guerrillas were not purporting to act as the regular government of a particular part of the state's territory but were seeking to bring down the existing regime throughout the territory by force of arms.' See also Jaconelli, n 50, p 337 'Private armies are excluded from the terms of the statute'. Also, Ibid, p 340 '[The Act] does not extend, however, to guerrilla forces which have failed to make such territorial advances nor, a fortiori, to the henchmen of those involved in organised crime.'

${ }^{80}$ Report, $\mathrm{n} 75$, para 32'Enlistment or recruitment for mercenary service on either side in an international conflict in which a Commonwealth country was a belligerent or on either side in any internal conflict which took place within the territory of a Commonwealth country would not be an offence under the Act.' The Report arose from the recruitment in the UK of some 160 men to serve with, or in support of, the armed forces of the FNLA in Angola in their struggle against the MPLA. The Report noted, para 3, that 'Active recruiting came to an end when it became known that a number of British mercenaries had been massacred by their own side in Africa.' See also Morris, n 50, p 271.

${ }^{81}$ Ibid, para 26.

${ }^{82}$ Ibid, para 37 'The task of assembling sufficient evidence to support a conviction from other witnesses in the foreign country where the mercenary served and persuading them to come here for the trial presents practical problems that would, in our view, be unsurmountable. They were considered to be so by the Director of Public Prosecutions in 1938 in connection with the enlistment of [UK] citizens for service in the Spanish Civil War.' See also Jaconelli, n 50, p 338 '[The Act confines] the offences to those of enlistment or recruitment (as opposed to one of service).'
} 
- A British subject - intent on evading it - could simply join the air force (or a specially created force) of a foreign belligerent State. Further, if a person has dual nationality, they might even be required to, and it would seem manifestly unjust to then convict them of a crime under English law; ${ }^{83}$

- The UK Government would only likely learn of the enlistment of British subjects in a foreign belligerent armies if this was widely publicised and the subject in question returned to the UK during the course of that $\operatorname{war}^{84}$ - something they would be unlikely to do.

Finally, the purposive element behind the Act should be understood re enlistment. In 1870, when this legislation was enacted, it was to prevent political embarrassment to the British Government. However, the chances of British subjects queuing up to enlist to fight in a war against a friendly State today is remote - not least when they cannot carry weapons with them when they leave the UK and when their chances of getting killed (unless they are military mercenaries) would be high. ${ }^{85}$ And, for the few of the latter that did, would they likely cause any embarrassment to the UK government? As for sections 5-7 of the Act - which deal with ships - they are a dead letter in modern times since they could easily be evaded by a British subject seeking to quit the UK, travelling by aircraft, car, rail etc as opposed to a ship.

\section{(f) Utility of the Foreign Enlistment Act 1870 today re-Enlistment}

As well as the above criticisms of the Foreign Enlistment Act 1870, its efficacy over the last 140 years should be considered. What seems clear is that it has proved to be a good example of legislation that proved to be unenforceable, in practice. It may be noted that:

- This Act was not utilised in the case of the $1^{\text {st }}$ World War (1914-18) or the $2^{\text {nd }}$ World War (1939-45). In part, this was, doubtless, because the UK was also at war with any possible friendly State, precluding the application of the Act. It may be noted that the UK, itself, has not been at war (as declared) since 1939. ${ }^{86}$ So have few other European countries;

- This Act failed to prevent British subjects from joining the French foreign legion - or to participate in the Spanish Civil War (1936-9).$^{87}$ In the case of the latter there was an official British policy of non-intervention. ${ }^{88}$ However, it is thought that c. 2,500- 4,000 volunteers from Britain went to Spain to fight, ${ }^{89}$ often in the British Battalion. ${ }^{90}$ Although the Civil War commenced in 1936, it was not until 9 January 1937 (after, at least, 700 British subjects had gone to Spain) ${ }^{91}$ that the British Cabinet decided

\footnotetext{
${ }^{83}$ In 1870 , the system of passports was undeveloped and, certainly, not the practice of dual nationality.

${ }^{84}$ If the war ended, one is sceptical whether there would be any appetite on the part of the English (British?) government to prosecute anyway.

${ }^{85}$ It should be remembered that, in 1870, there were no export restrictions on weapons (guns etc) unlike today (nor was it a criminal offence to carry a gun or knife in public places, as such, in Victorian times). As to British subjects (other than ex-military personnel) their military efficacy would also likely be very low - such that a foreign belligerent State would not likely want them in any case.

${ }^{86}$ AW Bradley \& KD Ewing, Constitutional and Administrative Law (15th ed, 2001), p 260 'In modern times, however, it has not been the practice to make a formal declaration of war before commencing military activity, as in the case of the invasion of Iraq in 2003.' At p 353 'No war has been formally declared since 1939...The Suez canal, the Falkland Islands, and the Gulf all received British armed forces on ministerial orders under the prerogative power to deploy those forces as the Crown thinks fit.' See also Crown Proceedings Act 1947, s 11 and Halsbury, n $8\left(5^{\text {th }}\right.$ ed), vol 3 para 116.

${ }^{87}$ On 17 July 1936 a nationalist military uprising took place in Spain against the Republican government. For general texts see: (a) R Baxell, Unlikely Warriors (Aurum Press, 2012); (b) R Baxell, British Volunteers in the Spanish Civil War: The British Battalion in the International Brigades 1936-1939 (2 ${ }^{\text {nd }}$ ed, Torfaen, Warren \& Pell, 2007); (c) W Rust, Britons in Spain. The History of the British Battalion of the XVth International Brigade (The Naval and Military Press, 2007). (d) SP McKenzie, The Foreign Enlistment Act and the Spanish Civil War 1936-1939. Twentieth Century British History, vol 10, no 1, 1999, pp 52-66.

${ }^{88}$ For the view of Stanley Baldwin [Prime Minister 1935-7] and the attempt by the British government to impose an embargo on arms sales, see Baxell, n 88 (text (a)) pp 44, 47.

${ }^{89}$ Baxell, n 88 (text (a), p 6 asserts that 2,500 volunteers from Britain, Ireland and the Commonwealth fought with the British Battalion, of whom some 500 died. He thought that an oft-quoted higher figure of 4,000 who volunteered was an exaggeration and included writers, journalists etc. See p 464, n 34. McKenzie, n 87, p 53 asserts that over 2,000 fought for the British Battalion.

${ }^{90}$ See Rust, $\mathrm{n} 87$.

${ }^{91}$ McKenzie, n 87, p 57. Baxell, n 87 (text (a)), p 58 'They [British volunteers] left for Spain in defiance of non-intervention and despite the British government's implementation of the Foreign Enlistment Act in January 1937, an obscure nineteenth-century piece of legislation which made volunteering to fight illegal.' Ibid, p 64 'In Britain, where the government was strongly opposed to any intervention in the
} 
to make the Foreign Enlistment Act 1870 applicable to the war in Spain. ${ }^{92}$ However, this had no effect, in practice, with many British subjects crossing the Channel on weekend boat train tickets. Although such trips abroad for the obvious purpose of enlistment were monitored by the Scotland Yard and MI5, those who took them were unimpeded - in part since passports were not required in those days for such a transit. ${ }^{93}$ As it was, no one was ever prosecuted under the Act in respect of British enlistment on either side in the Spanish Civil War. Thus, the Foreign Enlistment Act 1870 was a complete failure as a legal tool. ${ }^{94}$ This was mainly due to two reasons: (a) the difficulty of asserting that the Act applied to Spain when the British Government had not accorded de jure recognition to one party to that Civil War, $v i z$. Franco's fascists; ${ }^{95}$ (b) the inability to secure evidence of enlistment (or an agreement to enlist) robust enough for the purposes of a trial, ${ }^{96}$

- The 1976 Report indicated there had been no successful prosecutions under the Foreign Enlistment Act $1870 .{ }^{97}$ Further, it asserted that any claim by the State to exercise control over the enlistment of its citizens as mercenaries for service abroad involved a restriction on the freedom of the individual which must be justified on the grounds of public interest. ${ }^{98}$ As to this the Report noted the following: (a) to serve as a mercenary was not an offence under international law; ${ }^{99}$ (b) the protection by the State of a British subject from death or any injury if he enlisted in a foreign belligerent army (or navy) was insufficient to justify the prohibition of enlistment by the State. So too any argument that an irrecoverable expense might be incurred by the State in any repatriation of the same or that - if enlistment was prohibited - this would prevent exposing other British subjects in that country from retaliation; ${ }^{100}$

- The 1976 Report concluded that 'We think the provisions of the [Act] which relate to illegal enlistment have become thoroughly unsatisfactory in modern conditions. They should be repealed and a fresh start made. $^{101}$

Spanish struggle, recruitment had to be carried out in secret, particularly following the implementation of the Foreign Enlistment Act on 9 January 1937 and the banning of volunteers under the non-intervention agreement in February.'

${ }^{92}$ Ibid, p 58, 'A Press Notice was issued on $11^{\text {th }}$ January 1937 making it official that under the Foreign Enlistment Act to recruit or volunteer for the armed forces of either side in the Spanish conflict was illegal, and that those who did so would be "liable on conviction to imprisonment up to two years, or to a fine or to both a fine and imprisonment."

${ }_{93}$ Baxell, n 87 (text (b)), p 69 'For example, on 23 December 1936, a party of sixteen men described as 'suspected recruits for the Spanish Government Forces' were observed by a sarjeant from Special Branch, who reported that 'these men were all in possession of one-day excursion tickets from London-Dunkerque. Several of them were discretely questioned, but did not disclose their destination beyond Dunkerque. Special branch forwarded their surveillance reports to MI5, who drew up a huge list of 4000 individuals suspected of being potential volunteers. Most volunteers, however, were aware that the British authorities could do little more than take their suspects' names and make threats of future problems when - and if - they returned. It was 'only intimidation. They had no legal right to do anything about it', one volunteer recalled.' Rust, n 80, p 10 'Scotland Yard detectives fussed around the London office where the recruits were enrolled; they shadowed men; they threatened and blarneyed; and sometimes found a pretext for turning men back at the ports. But, if stopped at one port, the men merely presented themselves at another.'

94 McKenzie, n 87, p 52 'the act proved embarrassingly unenforceable.' Ibid, p 65 'The [Act] was an utter failure in the context of keeping British citizens out of the Spanish Civil War.'

${ }^{95}$ Ibid, p 55 'Would the government have to grant Franco de jure as well as de facto recognition in order for the Act to apply?' Archbold, n 50, para 25-294 makes clear its own position that the Act does not apply to civil wars 'The Act does not extend to enlistment in the government or rebel forces during a civil war in a friendly state.'

${ }^{96}$ As the Home Office noted, volunteers and their families would be unlikely to indicate their intention. Further, the secret service would not wish to provide evidence that would reveal their operations. See McKenzie, n 87, pp 60-1, 63-4. Ibid, p 62 'Over three-quarters of those who went to Spain to join the British Battalion did so after January 1937.'

${ }^{97}$ Report, $\mathrm{n} 75$, para 38. They also noted, para 7, the problems of defining what a 'mercenary' was and that they were 'driven' to adopt as a definition 'Any person who serves voluntarily and for pay in some armed force other than that of [HM] in the right of the [UK].' See also House of Commons Foreign Affairs Committee. Private Military Companies (HC Paper 2001-2) no 922, p 29 ('We conclude that an outright ban on all military activity abroad by private military companies would be counterproductive.)' See also Halsbury, n 8 ( $5^{\text {th }}$ ed), vol 3, para 12 , n 5. See also Morris, n 50, p 271 referring to Geneva Convention 1949, Protocol 1 (Additional), art 47 and Jaconelli, n 50, p 339 (difficult question of defining a mercenary).

98 Report, $\mathrm{n} 75$, para 10.

${ }^{99}$ Ibid.

${ }^{100}$ Ibid, para 15. Also 'we do not think there are any means by which it would be practicable to prevent a [UK] citizen from volunteering while he is abroad to serve as a mercenary and from leaving the [UK] to do so, we should regard any attempt to impose such a prohibition upon him by law as involving a deprivation of his freedom to do as he will which would require to be justified by a much more compelling reason of public policy then the prohibition of active recruiting of mercenaries within the [UK].'

${ }^{101}$ Report, n 75, para 41. As to what legislative steps might be taken in dealing with British subjects who sought to serve as foreign mercenaries, the Report stated, para 52 (7) 'Any new legislation should be directed to empowering [HM's] government to prohibit recruitment in the [UK] of mercenaries for service in specified armed forces abroad. The activities prohibited under this head should be 
In conclusion, it is asserted that the Foreign Enlistment Act 1870 - vis- $\grave{a}$-vis illegal enlistment - is a dead letter, and that this been so for over 140 years now. It is also asserted that there is also no reason why enlistment by a British subject in a foreign army (or navy) at war should be a crime - apart from in extraordinary circumstances which Parliament should specifically provide for in legislation which is 'tailor made' to deal with that particular contingency. ${ }^{102}$ Indeed, in a modern democracy, if British subjects wish to be (so foolish) as to participate in a foreign war they should be allowed to do so. Doubtless, few would try in modern times, especially if without military experience. Finally, recently, the Government, in order to prevent UK terrorists travelling abroad to attend terrorist training camps, has indicated that it will confiscate their passports, pursuant to the Crown prerogative to issue, or revoke, the same. ${ }^{103}$ This could be applied in the circumstances envisaged in the Foreign Enlistment Act 1870, re enlistment.

Thus, the Foreign Enlistment Act 1870 should, at least, in respect of enlistment, be repealed, being obsolete. The enlistment by a British subject in a foreign warring army (or navy) should only be a crime where this will have the palpable result of imperilling UK diplomatic and political relations with a friendly State. And, in the now (very rare) event of this being likely to occur, it would be appropriate for Parliament to enact modern legislation to deal with the precise fact situation. ${ }^{104}$

\section{FOREIGN ENLISTMENT ACT 1870 - ILLEGAL SHIPBUILDING Etc}

The Act makes it a crime if a person in HM dominions, without licence:

Builds or agrees to build, or causes to be built any ship with intent or knowledge, or having reasonable cause to believe that the same shall or will be employed in the military or naval service of any foreign state at war with any friendly state. ${ }^{105}$

So too, where a person: (a) issues (or delivers) any commission for; or (b) equips; or (c) dispatches (or causes or allows to be dispatched) any ship with such knowledge etc. Punishment is a fine and imprisonment - or either - at the discretion of the court. It is also a crime to aid the warlike equipment of foreign ships. ${ }^{106}$ Finally, the Act makes it a crime if a person in HM dominions, without licence:

Prepares or fits out any naval or military expedition to proceed against the dominions of any friendly state... ${ }^{107}$

widely defined so as to include publishing information as to how or where to apply for employment as a mercenary or how to get to the place where such employment is available, and making any payment or taking part in any arrangement to facilitate or promote such employment. (8) The provisions of the Act should be brought into effect in relation to particular armed forces by Order in Council (or other statutory instrument) requiring affirmative resolution by both Houses of Parliament specifying the forces to which it is to apply.' See also Morris, $\mathrm{n} 50$ p 271 'The Act is both ambiguous and outdated.' Ibid, p 272 'an unworkable, unfair and outdated Act.' See also Hansard (Commons) 10 February 1976, Harold Wilson PM 'The Act is now, I think, very much outdated in some particulars.'

${ }^{102}$ Ibid, para 41 says as much 'As to the maintenance of good relations between the [UK] and other States, it would be for [HM's] government when occasion arose to assess the extent to which these might be worsened with some State or groups of States (or, as is not impossible, improved) either by the fact that an active campaign for the recruitment of mercenaries was being conducted in the [UK] itself or by the mere failure of the [UK] government to prevent its citizens from going abroad to enlist.' (emphasis supplied). See also Jaconelli, n 50, p 341.

${ }^{103}$ See Anti-Social Behaviour, Crime and Policing Act 2014 and HO Circular 004/2014. Cf. Report, n 75, paras 16, 44 \& 52(6).

104 It may be noted that the Civil Contingencies Act 2004 enables regulations to be made in an emergency, albeit there are limitations on the same (see ss 22 \& 23). However, one is sceptical whether British subjects seeking to enlist in the terms of the current Foreign Enlistment Act 1870 would comprise an 'emergency' or, even if it did, whether the Act of 2004 is sufficiently extensive to prevent subjects from going abroad.

${ }^{105} \mathrm{~S} 8$ (penalty for illegal shipbuilding and illegal expeditions). Kenny, n 28, p 322 notes that 'The previous Act (of 1819) forbade nothing short of the ultimate 'equipping, fitting-out, or arming' of a ship.' See $A-G v$ Sillem (1864) 2 H \& C 431 (159 ER 178). Also, 81 Modern Law Review (1965) See also USA v Pelly (1899) [1899] WN 11 (delivery of vessels to the US Government for naval service use would have violated s 8, war having been declared between the US and Spain). See also Dyke v Elliott (1872) 8 Moo NS 428 (17 ER 373) (in the Franco-Prussian war, a French warship captured a Prussian ship in the English Channel as a prize of war, a French prize crew being put on board Due to bad weather, the prize ship entered British waters and was later towed under contract by a British tug into a French port. The JCPC held that this amounted to a crime under the Act, s 8 - the dispatching of a ship for the taking part in the naval service of a belligerent. The tug (called the Gauntlet) was, therefore, forfeited to the Crown).

${ }^{106} \mathrm{~S} 10$ 'If any person within the dominions of [HM], and without the license of [HM] - By adding to the number of the guns, or by changing those on board for other guns, or by the addition of any equipment for war, increases or augments, or procures to be increased or augmented, or is knowingly concerned in increasing or augmenting the warlike force of any ship which at the time of her being within the dominions of [HM] was a ship in the military or naval service of any foreign state at war with any friendly state...'

${ }^{107} \mathrm{~S} 11$ (penalty on fitting out naval or military expeditions without licence). $R v$ Sandoval (1887) 16 Cox CC 206 (an offence under s 11 is sufficiently constituted by the purchase of guns and ammunition in this country and their shipment for the purpose of being put on board a ship 
Every person engaged in such preparation or fitting out, or assisting therein, or employed in any capacity in such expedition is guilty of the crime. It may also be noted that the Treaties of Washington Act 1922 (repealed in 1959 $)^{108}$ made it a misdemeanour for a person - without licence from the Admiralty - with HM's dominions ${ }^{109}$ to build any vessel of war or to alter or equip any ship so as to adapt her for use as a vessel of war or to dispatch (or allow to be dispatched or delivered) from HM's dominions any ship so built, either entirely or partly within HM's dominions. ${ }^{110}$ As to the continued merits of these crimes of illegal shipbuilding, the following may be noted:

- The precedents are old and in the days when there were no export or import restrictions on military hardware. Today, restrictions can be imposed by the UK (or in the form of UN sanctions) on the export of military hardware to foreign countries (recent examples are Iraq and Yugoslavia). ${ }^{111}$ Making the building or equipping of military ships in the UK for export to countries of any foreign state at war with any friendly state subject to an export prohibition (contained in a Statutory Instrument) is a much more efficacious way of dealing with the problem - as opposed to making it a crime - since, obviously, UK industries will not then commence on any building/equipping, knowing they will not get an export licence;

- These crimes only apply to ships. Therefore, it is not a crime under the Act if a person builds or equips an aircraft, submarine ${ }^{112}$ etc.;

- The 'employment' of the ship must be in the military or navy of a State at war with a 'friendly state.' Thus, supplying the ship to a commercial arm of that State; or supplying the air force or special services of that State or supplying the ship to a third State (who then sells the same to the State at war) would not fall foul of the Act. In other words, the provisions of this Act, in modern times, can be easily circumvented.

In conclusion, today, there is a much more efficacious way of dealing with this problem, without the rigmarole and uncertainty of making it a crime. A Statutory Instrument may require an export licence for supplying military hardware to the warring State in question. Any person in the UK would not then go to the trouble of building or equipping in the first place, without such a licence. The problem is, therefore, solved at source as opposed to making it a distinct crime.

In conclusion, the Foreign Enlistment Act 1870 should be repealed in its entirety - both as to enlistment and as to illegal shipbuilding.

\section{INCITEMENT TO DISAFFECTION ACT 1934}

in a foreign port, with a knowledge of the purchaser and shipper and that they are to be used in a hostile manner against such a State, although the shipper takes no part in any overt act of war, and the ship is not fully equipped for the expedition within any part belonging to the Queen's dominions). R v Jameson [1896] 2 QB 425 (in relation to s 11, if there is an unlawful preparation of an expedition by a person within HM's dominions any British subject who assists in the same will be guilty of an offence under the $\mathrm{s} 11$ even though he renders assistance from a place outside HM's dominions). The International (1871) 1871) LR 3 A \& E 321 (during the Franco-Prussian war of 1870-71, an English company contracted with the French government to lay down a series of telephone cables on the French coast. It was held that the object of the contract was to furnish ordinary postal telegraphy, although it was also possible the line might be partially used by the French military for communications).

${ }^{108}$ Holdsworth, $\mathrm{n} 24$, vol 14, p 80 refers also to the treaty of Washington in 1871 in which the duties of a neutral in respect of vessels within its jurisdiction, intended to conduct warlike operations on behalf of a belligerent, were defined. See also the Hague Convention of 1907. See also Hall, n 33, pp 609, 735, n 2 and Cobbett, n 53, vol 2, p 474.

109 This meant all HM's dominions apart from India and the self-governing dominions.

110 This Act was amended by the London Naval Treaty Acts 1930 and 1937 (both rep 1963). See also Russell, n 22, p 1547. Where there was reasonable ground to believe that a ship had been or was being built etc, the Admiralty was empowered by the Act, $\mathrm{s} 2$, to issue a warrant for its seizure, search and detention. See also Harris, n 59, p 117.

${ }^{111}$ For example, for countries subject to UN sanctions there is generally a prohibition, or the export of certain goods (usually of a military or dual use nature) except under the authority of a licence issued by the Secretary of State. The goods may be forfeited if exported contrary to sanctions. For countries currently subject to UN sanctions, see the export control section of the Department of Trade and Industry website, http://www.berr.gov.uk. For a Victorian proclamation re exportation, see Exp Chavasse, (1865) 4 De GJ \& Sm 655 (46 ER 1072 ), at p 662.

112 The Act, s 30 (interpretation) specifies 'Ship" shall include any description of boat, vessel, floating battery, or floating craft; also any description of boat, vessel, or other craft or battery, made to move either on the surface of or under water, or sometimes on the surface of and sometimes under water.' Although this definition is fairly wide, the first mass produced submarines only occurred in 1881 and - in the European military context - submarines only became significant in World War I (1914-18). Therefore, it is asserted that the definition of ship in the Act will not cover submarines. 
Prior to discussing the Incitement to Disaffection Act 1934 (the '1934 Act') it is relevant to consider prior - and related - legislation. Namely, the Incitement to Mutiny Act 1797 (repealed in 1998) and the Police Act 1919 (replaced by the Police Act 1964, itself replaced by the Police Act 1996).

\section{(a) Incitement to Mutiny Act 1797}

This Act was the "product of an anxious decade which followed upon the French revolution. ${ }^{113}$ Britain had been at war with France since 1793 and, in 1797, there were mutinies in the navy in the fleet at Spithead and at The Nore (an anchorage in the Thames estuary). ${ }^{114}$

- As a result of them, the Incitement to Mutiny Act 1797 was enacted. It lapsed in 1805 but was revived in 1817. It imposing the death penalty (later reduced to life imprisonment) if a person 'maliciously and advisedly' endeavoured to seduce any member of HM's forces from his duty and allegiance to HM or to make (or endeavour to make) any mutinous assembly or to commit any treasonable or mutinous practice whatsoever; $^{115}$

- However - probably reflecting the fact that this Act had been something of a political panic measure there were no (it has been asserted by Williams) prosecutions under it in the period 1804-1912 $2^{116}$ - even though there were a number of riots in this period in which troops were involved in order to quell them, during which civilians encouraged the troops not to fire on them or not to otherwise fully comply with orders. $^{117}$

After 1912 - until the repeal of the Incitement to Mutiny Act 1797 in 1998 - there were few prosecutions:

- In 1912, five people were prosecuted under the Act, during a time of industrial strife, for seeking to undermine the loyalty and obedience of British soldiers. ${ }^{118}$ Their short term of imprisonment was later reduced, the Home Secretary exercising the prerogative of mercy. ${ }^{19}$ One of the rulings made during these cases was that the an indictment brought under the Act did not need to specify any particular member(s) of the armed forces who had been approached; ${ }^{120}$

- In 1925, twelve communists ${ }^{121}$ were prosecuted for inciting persons to commit breaches of the Act as well as for seditious libel. ${ }^{122}$ They were sentenced to 6 or 12 months imprisonment;

\footnotetext{
${ }^{113}$ D Williams, Keeping the Peace (Hutchinson \& Co, 1967), p 179. See also Law Commission, Statute Law Commission, $16^{\text {th }}$ Report in respect of the Draft Statute Law (Repeal) Bill 1998, p 48. Also, Law Commission. Codification of the Criminal Law. Treason, Sedition and Allied Offences. Working Paper no 72 (1977), para 80.

114 As Williams, n 113, p 179 notes, these mutinies were mainly as a result of harsh discipline, low pay and several other grievances.

115 Section 1. This was extended to the air force under the Air Force (Constitution) Act 1917, s 13. See also Kenny, n 28 (1999 ed), p 411.

${ }^{116}$ This assertion of Williams would not appear to be correct, see $R v$ Fuller (1797) 2 Leach 790 (168 ER 495), 1 East 92 (an indictment under the Act for seducing soldiers need not set out the means used for that purpose nor aver that the prisoner knew the person endeavoured to be seduced to be a soldier. Fuller had produced several 'inflammatory and seditious handbills calculated to incite the army to mutiny', it was asserted by the prosecution). See also $R v$ Tierney (1804) Russ \& Ry 74 (168 ER 691) (endeavoured to seduce sailor to take an oath to be true to certain false and wicked traitors). For an inappropriate private prosecution in 1858, see Williams, n 113, p 180. See also Russell, n 22 (1936 ed), pp 114-5.

117 Williams, n 113, p 181 .

${ }^{118}$ See $R v$ Bowman (1912) 22 Cox CC 729. A monthly socialist newspaper, The Syndicalist, had published an Open Letter to British Soldiers. The case is discussed in T Mann, Tom Mann's Memoirs (Spokesman, 1923), chs 20 \& 21 which contains the Letter (the offending passage was principally 'Boys [a reference to soldiers] don't do it! Thou shalt not kill, says the Book [the Bible]. Don't forget that.') statements made in Parliament and details of the trial. Mann, a socialist, was one of those prosecuted and was sentenced to 6 months imprisonment. The others prosecuted were Fred Crowsley (who had distributed the magazine), Benjamin and Ernest Buck (who had printed it) and Guy Bowman (the editor). See also R Jackson, The Chief. The Biography of Gordon Hewart Lord Chief Justice of England 1922-40 (Harrap, 1959), pp 52-4.

119 See Williams, n 113, pp 182-4.

${ }^{120}$ As Williams, n 113, pp 184-5 notes, 'Speeches at public meetings and widely distributed literature could thus lend themselves to prosecution, and the prosecutors would not need to trace members of the audience or any actual readers. Quite obviously, the [Act] was going to be turned to again in any periods of industrial stress.'

${ }^{121}$ They included veteran communists Harry Pollitt (1890-1960, sometime General Secretary of the Communist party), William Gallacher (1881-1965, founding member of the British Communist party) and Wal Hannington (1896-1966, founding member of the British Communist party). See the account of Pollitt, see H Pollitt, Serving my Time (Lawrence \& Wishart, 1950), pp 211-53. W Hannington, Unemployed Struggles 1919-1936 (Lawrence \& Wishart, 1977), p 137 asserts that 'The charge of incitement to mutiny amongst his majesty's forces was made on the grounds that in our speeches and in our press we had urged that in the event of a general strike and the
} 
- In 1926, a communist MP, Shapurji Saklatvala (1874-1936), was imprisoned for two months for a speech supporting striking miners which, in part, incited members of the armed forces to abandon their duty. ${ }^{123}$ In 1933, two communists were imprisoned under the Act for inciting sailors to mutiny. ${ }^{124}$ In 1933, four communists were imprisoned under the Act for distributing literature at Newport barracks. ${ }^{125}$

Williams notes:

The Government had by now [i.e. by 1933] come to regard the [Act] as a cumbersome weapon to combat more than sporadic efforts to cause disaffection. Moreover, it was too severe a law to invoke against the mere distributor of subversive literature when behind the scenes a 'somewhat sly and almost skulking breed of inciter' kept well outside the range of the police. What was needed was a totally new provision which would enable summary trial as well as trial by jury of people inciting disaffection and which would, at the same time, give new powers to help the authorities to track down the men behind the scenes. This, at least, was the view of the Government and the result was the introduction of the controversial Incitement to Disaffection Bill of $1934 .{ }^{126}$

In short, in the lifespan of the Incitement to Mutiny Act 1797 from 1797-1998 (201 years) there were only five sets of convictions. All of them were during times of high political tension. In 1977, the Law Commission recommended the repeal of this Act. ${ }^{127}$

\section{(b) $\underline{\text { Police Act } 1919}$}

This Act was the first to make it a crime to incite disaffection among the police. It was enacted after a strike among the Metropolitan and the City of London forces (further, while this Bill was proceeding through Parliament in 1919 there were attempt to call out the police on strike throughout the country).

- As Williams notes, the Home Secretary (E Shortt) at the time denied that the Bill was aimed at trade unions and their influence on the police. Rather, it was directed 'at the agent of disaffection and of revolution and the agent of real mischief.' 128

- The Act made it a misdemeanour punishable with 2 years imprisonment to cause or do any act calculated to cause disaffection among the members of any police force, or to induce any member of such a force to commit breaches of discipline. ${ }^{129}$ There appear to have been a few cases under the Act. ${ }^{130}$

\footnotetext{
soldiers being called upon to use their arms against the workers, they should remember their working-class origin, and not be ready to shoot their own brothers.'

${ }^{122}$ Williams, $\mathrm{n} 113, \mathrm{p} 185$. The passages in question were in the Workers' Weekly, the official journal of the Communist party.

${ }^{123}$ Ibid, p 186.

${ }^{124}$ Ibid. One was sentenced to 3 years, another to 20 months imprisonment. It may be noted that there was also the Naval Enlistment Act 1853 (rep) which made it an offence to approach or hover about any of HM's ships for the purpose of aiding any officer, seaman, or marine to desert or absent himself. See Williams, n 113, p 191. The residue of this Act was repealed in 1969.

125 Ibid.

${ }^{126}$ Williams, n 113, p 187.

${ }^{127}$ Law Commission Working Paper, n 113, paras 80-94.

${ }^{128}$ Williams, n 113, p 193. He also quotes the Earl of Jersey who, in moving the second reading in the House of Lords on $5^{\text {th }}$ August and referring to the recent abortive strike stated 'The evils resulting from a police strike, even from a strike on so small a scale as that which has recently taken place, must be apparent to everyone. Those evils have been deliberately created, and are now being fostered, by a campaign of wilful misrepresentation and falsehood.'

${ }^{129}$ See also Kenny (1966 ed), n 28, p 411. See also Harris, n 59, pp 109-10.

${ }^{129}$ See also Harris, n 59, pp 109-10.

${ }^{130}$ Williams, n 113, pp 192-5 (writing in 1967) refers to the following: (a) in 1921 a man was sentenced to 6 months imprisonment for a speech to a gathering of the unemployed in which he stated 'Policemen! You fought for us in France. Don't help the capitalists now.'; (b) in 1921, Mary Thring (1887-1964) a suffragette was editor of a paper published by the National Administrative Council of the Unemployed. It published an article 'To the Coppers' which was accompanied by a drawing of police 'zooping the unemployed with batons'; this was published after a hunger march clash with police in Trafalgar Square, London. She was fined $£ 10$ and bound over for 10 months; (c) in
} 
This Act was replaced by the Police Act 1964, section 53. ${ }^{131}$ This Act was repealed in 1996, and the current Police Act 1996, s 91 provides that a crime is committed in the case of:

Any person who causes, or attempts to cause, or does any act calculated [likely $]^{132}$ to cause, disaffection amongst the members of any police force, or induces or attempts to induce, or does any act calculated to induce, any member of a police force to withhold his services.

On summary conviction, imprisonment shall not exceed 6 months ${ }^{133}$ (or a fine not exceeding the statutory maximum) or both. On conviction on indictment, imprisonment shall not exceed 2 years or a fine or both. The section also applies to members of the British Transport Police Force, to special constables appointed for a police area and to Ministry of Defence police. ${ }^{134}$

In light of the Incitement to Mutiny Act 1797 and the Police Act 1996, the background to the Incitement to Disaffection Act 1934 will be considered.

\section{(c) Background to the Incitement to Disaffection Bill 1934}

Williams noted that this Bill was popularly known as the 'Sedition Bill' and - between the second reading of the Bill (on 16 April 1934) ${ }^{135}$ and its royal assent (on 16 November) - there was much public criticism of its terms, including from Sir William Holdsworth. Even though various important amendments were made to the Bill prior to enactment, there was still considerable disquiet that the Bill was repressive and too wide. ${ }^{136}$ As it is, the Incitement to Disaffection Act 1934 is entitled 'An Act to make better provision for the prevention and punishment of endeavours to seduce members of Her Majesty's forces from their duty or allegiance.' Section 1 provides that it is a crime:

If any person maliciously and advisedly endeavours to seduce any member of [HM's] forces from his duty or allegiance to $[\mathrm{HM}]^{137}$

Section 2(1) provides for another crime:

If any person, with intent to commit or to aid, abet, counsel, or procure the commission of an offence under [ $\mathrm{s} 1]$, has in his possession or under his control any document of such a nature that the dissemination of copies thereof among members of [HM's] forces would constitute such an offence, he shall be guilty of an offence under this Act.

A judge can issue a search warrant to obtain evidence with notification to the person searched and the retention of evidence. ${ }^{138}$ On conviction, the maximum sentence is 2 years imprisonment or a fine of $£ 200 .{ }^{139}$ However, no prosecution can occur without the consent of the Director of Public Prosecutions. ${ }^{140}$ The Act applies to Scotland and Northern Ireland, with modifications. ${ }^{141}$ As to prosecutions under this Act, Halsbury's Statutes refers only to $R v$ Arrowsmith (1975) ${ }^{142}$ In this case, the defendant distributed literature to soldiers at Winchester suggesting they should leave the army or desert rather than serve in Northern Ireland. She was

1932, Wal Hannington (see n 121) was imprisoned for 3 months for a speech at Trafalgar Square in which he was convicted of attempting to cause disaffection among the Metropolitan police. For Hannington's account see Hannington, n 121, pp 255, 259-66.

${ }^{131}$ See also Williams, n 113, p 192.

132 The word 'calculated' likely means 'likely' see Law Commission Working Paper, n 113, para 88. See also G Williams, Criminal Law, The General Part ( $2^{\text {nd }}$ ed), p 66.

133 Or 12 months, see Archbold, n 50, para 25-320.

${ }^{134}$ For the latter see Ministry of Defence Police Act 1987, s 6.

${ }^{135}$ It was moved by Sir Thomas Inskip, the Attorney-General.

136 Williams, n 113, pp 187-8. See also Law Commission Working Paper, n 113, para 82.

${ }^{137}$ See also Halsbury, n 8 ( $5^{\text {th }}$ ed), para $363, \mathrm{n} 1$ 'S 1 creates a single offence which is committed by a person who endeavours to seduce members of the forces with a particular intent. The intent may be to seduce them from their duty or from their allegiance or both.'

${ }^{138} \mathrm{~S} 2(2)$.

${ }_{139}$ S 3 (1) A person guilty of an offence under this Act shall be liable, on conviction on indictment to imprisonment for a term not exceeding two years or to a fine not exceeding two hundred pounds, or on summary conviction to imprisonment for a term not exceeding four months or to a fine not exceeding twenty pounds, or (whether on conviction on indictment or on summary conviction) to both such imprisonment and fine.

${ }^{140}$ S 3(2). Ibid, s (3) (3) 'Where a prosecution under this Act is being carried on by the Director of Public Prosecutions, a court of summary jurisdiction shall not deal with the case summarily without the consent of the Director.'

141 Ibid, s 4.

142 [1975] QB 678. 
sentenced to imprisonment of 18 months, though this was later reduced. The Court of Appeal (Lawton LJ) opined that 'This leaflet is the clearest incitement to mutiny and to desertion.', 143

\section{(d) Observations on the Incitement to Disaffection Act 1934}

Williams noted that:

- The Act of 1797 used the words 'maliciously and advisedly' and this was inserted at the second reading into the 1934 Act. ${ }^{144}$ 'maliciously' means that an accused's conduct should be intentional or reckless and 'advisedly' probably means 'knowingly' ${ }^{145}$ or - in other words - it implies the accused must be aware the person he is seeking to influence is, in fact, a member of the forces. ${ }^{146}$

- There was a power of search where an offence was suspected on reasonable grounds. Williams notes that 'The Bill initially provided that a search warrant could be issued by a magistrate. In face of expressed doubts about the political impartiality of some magistrates the power was finally entrusted only to a High Court judge. ${ }^{147}$

- The 1797 Act referred to seducing a serviceman from his duty and allegiance. The 1934 Act substitutes an 'or'. The effect, almost certainly, increases the ambit of the Act. ${ }^{148}$ In $R v$ Arrowsmith (1975) Lawton LJ noted that allegiance applied to members of HM's forces whether an oath of allegiance had been taken or not; ${ }^{149}$

- The 1934 is very wide in scope - unnecessarily so. ${ }^{150}$

Writing in 1967, Williams stated that there had only been one prosecution under the Act (which was not referred to in $R v$ Arrowsmith, above). In 1937 a student was imprisoned for 1 year for allegedly seeking to induce a leading RAF aircraftsman to steal an aircraft and fly it to Spain. ${ }^{151}$ Williams also stated:

Today, as the [Act] lies a little forlorn on the statute book, one is tempted to dismiss many of the misgivings of 1934 as either exaggerated or totally without foundation... It remains true, however, that the [Act] and it's still surviving predecessor of 1797 are of potential importance in times of crisis, not least in times of industrial strife or other civil disturbance. ${ }^{152}$

\footnotetext{
${ }^{143}$ At $\mathrm{p}$ 688. See also Archbold, n 50, para 25-322.

${ }^{144}$ Williams, n 113, p 188 'When it was first introduced the 1934 Bill left out 'maliciously and advisedly' or equivalent phrase, but it was inserted within a short time of the second reading in the House of Commons.' In $R v$ Arrowsmith [1975] QB 678 it was held, per curiam, that the word 'maliciously' in the section meant 'wilfully and intentionally'. See also [1975] Crim LR 161-2 and $R$ v Solanke [1970] 1 WLR 1 (maliciously in the Offences against the Person Act 1861, s 16 means wilfully or intentionally). There is no basis in reading into the 1934 Act, however, the words 'without lawful excuse'. See Halsbury, $\mathrm{n} 8\left(5^{\text {th }} \mathrm{ed}\right)$, vol 25, para 363 and $R v$ Arrowsmith [1975] QB 678 per Lawton LJ at $\mathrm{p} 689$.

${ }^{145}$ See also Law Commission Working Paper, $\mathrm{n}$ 127, para 80. $R$ v Fuller (1797) 2 Leach 790 (168 ER 495) per Perryn B at $\mathrm{p} 798$ 'they [the judges] are of opinion that the word 'advisedly' in the indictment is equivalent to the word 'knowingly'. Today, a civilian guilty of persuading, or assisting, a soldier to desert is governed by the Armed Forces Act 2006, s 344. See also Archbold, n 50, para 25-322-4.

${ }^{146}$ Williams, n 113, p 188 'When it was first introduced the 1934 Bill left out 'maliciously and advisedly' or equivalent phrase, but it was inserted within a short time of the second reading in the House of Commons.'

${ }^{147}$ Ibid, p 189. He continues 'Even so, lest the spectre of General Warrants be waved before them, the Government provided for the issue of search warrants in unusually elaborate terms. A search warrant can be issued only in respect of an offence suspected to have been committed within the previous three months; documents seized must be listed and a time limit is imposed upon their detention; and ...it is provided that the only material which can be seized is that which the police reasonably suspect to be evidence of the commission of an offence under the Act.'

${ }^{148}$ Ibid, n 113, p 189 'In truth, it represented a major advance on the 1797 Act...How far the scope is widened we have yet to see, but it is arguable that some approaches to soldiers not to fire on strikers or other civilians could be directed at their duty to obey orders and not to their allegiance to the Crown.' See also Law Commission Working Paper, n 113, para 83 (no authority on the meaning of the word 'or' in this Act or 'and' in the Incitement to Mutiny Act 1797).

149 [1975] QB 678 at p 657 'A man owes allegiance to the Crown, whether he has taken the oath of allegiance or not.'

${ }^{150}$ See also (1935) Law Quarterly Review vol 51, p 41 (re the tendency to make statutes too comprehensive and so give too general an authority to the executive).

${ }^{151}$ Williams, n 113, p 190.

152 Ibid.
} 
Writing in 1977, the Law Commission observed that this Act had been 'little used since its introduction' and that between 1956 and 1974 there were only four prosecutions. Further, in 1975, fourteen people were charged under the Act but acquitted. ${ }^{153}$ As to the retention of this Act, the Law Commission did not seek views on the need to retain it but it proposed that, if retained, it be amended:

- by replacing the words 'maliciously and advisedly' in s 1 by words 'more in accord with the modern form of words in criminal statutes;'

- by making it clear that the offence requires an intention to induce a member of the forces to commit a fundamental breach of his duty, amounting to a breach of allegiance. ${ }^{154}$

\section{(e) Abolish or Amend the Incitement to Disaffection Act 1934?}

It would seem appropriate - and, indeed, wise - to retain a crime to punish those who seek to persuade military personnel not to perform their duty. As a result, one would assert that the concept of the Act should not be abolished. However, there would seem to be no good legal reason for a disparity between the Police Act 1996 and the Act of 1934 - not least when the former actually includes military police within its ambits. The former, s 91 provides that a crime is committed if:

Any person who causes, or attempts to cause, or does any act calculated [likely $]^{155}$ to cause, disaffection amongst the members of any police force, or induces or attempts to induce, or does any act calculated to induce, any member of a police force to withhold his services.

The concept of causing 'disaffection' is better than the more antiquated wording in the Act of 1934 of a person 'maliciously and advisedly' endeavouring 'to seduce'. However, neither concept has kept up with the development of the law, where the concept of 'incitement' is more prevalent. Thus, one would propose that the crime in respect of both police and forces personnel should be one of 'inciting' them not to perform their 'duty'. The latter is better than 'withholding services'. Further, it is asserted that 'attempting to cause' is too nebulous and unnecessary. Thus, the crime should require actual incitement - which could be by speech, word or act). In the case of forces personnel one would argue that reference to allegiance is not actually necessary since some personnel take no oath. ${ }^{156}$ Further allegiance to the Crown is implicit in the word 'duty' - their duty (as that of the police) is to the Crown. In conclusion, it is asserted that it should be a crime if:

Any person incites any member of the police force or of the armed forces not to perform their duty. ${ }^{157}$

Even if that wording were not acceptable, modelling the 1934 Act on the Police Act 1996 would be better than the present position.

In conclusion, the Incitement to Disaffection Act 1934 should be repealed and the crime should be the same as that contained in the Police Act 1996, both being modernised.

\section{ALIENS RESTRICTION (AMENDMENT) ACT 1919}

\section{(a) Sedition or Disaffection}

\footnotetext{
${ }^{153}$ Law Commission Working Paper, $\mathrm{n} 113$, para 84. See also $R v$ Williams \& Others. The Times. 11 December 1975 (two defendants were convicted of assisting deserters, contrary to the Army Act 1955, s 192). The Law Commission also referred to a case in Scotland in 1975 which was dropped (The Lord Advocate directed the dropping of charges against 4 defendants of contravening s 1 by distributing leaflets to marines at any open day). The Law Commission also mentions a case at Preston Crown Court where no evidence was offered by the prosecution on a charge of possession of a leaflet contrary to the Act, s 2).

${ }^{154}$ Law Commission Working Paper, n 113, p 62.

155 The word 'calculated' likely means 'likely' see Law Commission Working Paper, n 113, para 88. See also G Williams, Criminal Law, The General Part ( $2^{\text {nd }}$ ed), $\mathrm{p} 66$.

${ }^{156}$ Allegiance is also based on the person being a British subject or otherwise subject to protection by the Crown in return for acknowledging their subjection to the same.

${ }^{157}$ Possibly, one could add 'or withhold their services'. And even 'or withhold their services or allegiance' since the allegiance of the police is also to the Crown.
} 
This Act was enacted 'at the height of the post-war [i.e. post World War I (1914-18)] suspicion of aliens. ${ }^{158}$ Section 3 provides that it is a crime:

If any alien attempts or does any act calculated or likely to cause sedition or disaffection amongst any of [HM's] forces or the forces of [HM's] allies, or amongst the civilian population.

Liability, on conviction, is imprisonment for a term not exceeding 10 years or on summary conviction, to imprisonment for a term not exceeding 3 months. As to this section, Williams stated:

It will be noticed that the offence carries severe penalties and that, as in section 53 of the Police Act, ${ }^{159}$ it is arguable that a guilty intention is not always a necessary element. The potential scope of the offence is also very great since the term 'sedition' is used as well as 'disaffection', and sedition.... is a crime of very uncertain extent. ${ }^{160}$

The crime of sedition was finally abolished in the Coroners and Justice Act 2009. ${ }^{161}$ However, it had long been in decline before that, with some very aberrant decisions, ${ }^{162}$ and the Law Commission, in 1977, had recommended its abolition. ${ }^{163}$ Given the abolition of sedition in general, there would appear to be no good legal reason to retain sedition solely for the purposes of this crime. As to the remainder of s 3, the wording partly duplicates the Incitement to Disaffection Act 1934. The two may be compared:

If any person maliciously and advisedly endeavors to seduce any member of [HM's] forces from his duty or allegiance to [HM] (Incitement to Disaffection Act 1934)

If any alien attempts or does any act calculated or likely to cause...disaffection amongst any of [HM's] forces or the forces of [HM's] allies, or amongst the civilian population (Aliens Restriction (Amendment) Act 1919)

The Act of 1919 is more restricted that the Act of 1934 in some ways and wider in others.

- The 1934 Act refers to 'any person'; the 1919 Act to 'any alien'. Today, there is no good reason to restrict the crime to foreigners. This is unnecessarily discriminatory. As it is, most crimes under English law are general in purport. Thus, the 1934 Act is to be preferred;

- The 1934 Act refers to 'HM forces'. So does the 1919 Act. However, the latter also refers to the 'forces of HM's allies.' There is no need for the latter in modern times and it is for the laws of allied countries to made provision for the same as a crime, if they deem it necessary. It is also uncertain what the word 'allies' means - especially when the UK is not (as today) at war with any other State;

- The 1919 Act also refers to disaffection being caused among the 'civilian population' - wording very vague and uncertain, in ambit. It would also appear this crime can be committed where no violence is intended. Indeed, it seems, without any need for malice or deliberate intention. ${ }^{164}$ Thus, the Law Commission, in 1977, noted: 'Whatever the meaning of 'calculated' here, where it is used disjunctively with 'likely', the very use of the word 'likely' indicates the width of the offence. It can be committed without any mental element on the part of the defendant. For it to be an offence in peacetime to do an act likely to cause disaffection among the forces or the civilian population without any requirement of intention is a remarkable example of legislation which is surely out of date.'

Thus, at best, it is asserted that this Act should be curtailed so that it makes it only a crime if 'any alien attempts or does any act calculated or likely to cause...disaffection amongst any of [HM's] forces'. However, the same is

\footnotetext{
${ }^{158}$ Williams, n 113, pp 195-6. Also, Halsbury, n 8 ( $5^{\text {th }}$ ed), para 411, ns 10 \& 11.

159 See n 131

160 Ibid, p 196.

${ }^{161}$ See s 73.

${ }^{162}$ See generally, GS McBain, Abolishing the Crime of Sedition - Part 1 (2008) 82 ALJ 543-79 and GS McBain, Abolishing the Crime of Sedition - Part 2. (2009) 83 ALJ 449-85.

${ }^{163}$ Law Commission Working Paper, n 113, paras 89, 94 \& 96(10).

${ }^{164}$ For example, if I argue for the abolition of the House of Lords or the monarchy in a speech to a crowd is this inciting disaffection? And, if I argue to a select group of workers, that their pay and conditions should be improved, can they be said to comprise 'the civilian population' or are they just a small part of it, and the Act not apply?
} 
better provided for in the later Act of 1934, in that it applies to 'any person' and not just to 'aliens.' As a result, it is asserted that this crime is too vague and unnecessary and it should be abolished.

\section{(b) Promoting Industrial Unrest}

The 1919 Act contains another crime with s 3(2) stipulating:

If any alien promotes or attempts to promote industrial unrest in any industry in which he has not been bona fide engaged for at least two years immediately preceding in the [UK]

Liability, on summary conviction, is imprisonment for a term not exceeding 3 months. As to this section Williams noted that:

In the House of Commons the Home Secretary was anxious to reassure members that this unusual provision was not directed against aliens who became genuinely involved in industrial disputes and went on strike; rather, it was aimed at aliens who entered this country with the deliberate intention of fomenting unrest and discord in industrial relations. At that period a number of aliens were suspected of revolutionary and subversive activities in this country, and several were in fact deported during $1919 .{ }^{165}$

In modern times - and with modern trade union legislation - this section is unnecessary. Also, there is no evidence or concern, today, of aliens flocking to the UK to promote 'industrial unrest'. Nor is there - in any case - good legal reason to limit the crime to aliens. Further, the concept of 'industrial unrest' - as well as that of 'promoting' the same is - it is asserted - too nebulous wide and vague in modern times to constitute a criminal offence. ${ }^{166}$ So too, the concept of a person being 'bona fide engaged' in an industry. Finally, a coach and horses can be driven through this section simply by a foreign agitator waiting for two years, prior to commencing on his otherwise nefarious conduct.

\section{(c) Abolishing the Aliens Restriction (Amendment) Act 1919}

There do not appear to have ever been any prosecutions under this Act. It was also the provisional view of the Law Commission in 1977 that this Act 'can now safely be repealed.' In the intervening 30 plus years there has been nothing to refute such a view. In any case, the Act overlaps, to a major extent, the Act of 1934 (see 4).

In conclusion, it is asserted this Act should be repealed.

\section{CONCLUSION}

It is vital, in a modern democracy, that the law - including the criminal law - is up-to-date and relevant. Further, activities should only be crimes where there is good legal reason. As to the three antiquated pieces of legislation which I have considered, it is asserted that two of them should be abolished outright and the third re-worded to be the same as the equivalent crime relating to the police.

- Foreign Enlistment Act 1870. There never has been a successful prosecution under this Act. In any case, in a modern democracy, British subjects should be able to enlist in foreign armies - even if they are at war with a friendly State - unless this would materially impact on the UK government's foreign relations. Thus, this Act should be repealed and 'tailor-made' legislation enacted, if and when required (which is most unlikely). In respect of crimes contained in this Act concerning the building, and equipping, in the UK of ships to be used by foreign warring States, it is better if they are abolished with export restrictions imposed, where required (breach of the same would be a crime);

- Incitement to Disaffection Act 1934. This Act should be amended so as to tally with the Police Act 1996, s 91;

\footnotetext{
165 Williams, n 113, p 196. See also R McMahon, Aliens and Industrial Unrest: The Position of EU Citizens. Statute Law Review. Vol 16 (1995), p 98 et seq.

${ }^{166}$ It is noteworthy that the Oxford English Dictionary contains no definition of 'industrial unrest'.
} 
- $\quad$ Aliens Restriction (Amendment) Act 1919. This Act should be repealed. It is unnecessary in modern times as well as being too vague and nebulous in ambit.

\section{Copyrights}

Copyright for this article is retained by the author(s), with first publication rights granted to the journal.

This is an open-access article distributed under the terms and conditions of the Creative Commons Attribution license (http://creativecommons.org/licenses/by/3.0/). 